\title{
PENGUKURAN EFISIENSI DAN EFEKTIVITAS PELAYANAN ANGKUTAN BIS DI KAWASAN PERKOTAAN BINTUNI
}

\author{
Ricky Doddy Sianturi (1), Dr. Iwan Pratoyo Kusumantoro (2) \\ (1) Staf Pengajar, Program Studi Logistik, ITHB. (ricky@ithb.ac.id) \\ (2) Staf Pengajar, Sekolah Arsitektur Perencanaan dan Pengembangan Kebijakan (SAPPK), ITB. (ipkus@pl.itb.ac.id)
}

\begin{abstract}
Abstrak
Angkutan umum, khususnya pelayanan angkutan umum merupakan fasilitas dan pelayanan esensial yang disediakan oleh pemerintah untuk memenuhi kebutuhan dasar masyarakat. Kegagalan persaingan pasar dalam penyediaan layanan angkutan umum di daerah yang tidak memberikan keuntungan finansial menuntut pemerintah daerah mengisi ketiadaan dengan motif-motif yang kurang menguntungkan. Pemerintah Bintuni menerapkan konsep angkutan berbasis bus dengan mengoperasikan Angkutan Masyarakat Bintunu (AMB) di wilayah perkotaan kecil dengan tingkat isolasi dan ketimpangan yang tinggi, karakteristik pedesaan yang kuat, jumlah penduduk yang rendah, dan kondisi ekonomi subsisten. Analisis kinerja melalui pengukuran efektivitas dan ketimpangan Efisiensi pelayanan angkutan umum merupakan sarana yang sangat berguna untuk menjamin kelangsungan dan peningkatan kualitas pelayanan secara berkala. Tujuan dari penelitian ini adalah untuk menganalisis kinerja ekonomi pelayanan AMB dari sudut pandang pemerintah. Pengukuran kinerja dilakukan untuk menilai seberapa efektif dan efisien sumber daya keuangan digunakan untuk menghasilkan layanan, bagaimana produksi layanan digunakan oleh pengguna, dan bagaimana pengaruhnya terhadap pemerintah. Melalui metode pengukuran rasio antara komponen kinerja, benchmarking, dan pembentukan indeks komposit dapat diukur tingkat efisiensi biaya, efektivitas pelayanan, dan efektivitas biaya saat ini, gap kinerja dari standar pelayanan yang optimal, dan variabel yang harus diintervensi. meningkatkan efisiensi dan efektivitas pelayanan AMB. Hasil penelitian menunjukkan bahwa efisiensi dan efektivitas pelayanan AMB masih dibawah standar pelayanan yang optimal. Rendahnya kelayakan finansial layanan AMB disebabkan mahalnya biaya pembuatan jasa transportasi yang tidak dapat diimbangi dengan pendapatan dari konsumsi jasa oleh pengguna dan tarif yang dikenakan sehingga layanan AMB sangat bergantung pada subsidi pemerintah.
\end{abstract}

Kata kunci: Analisis Kinerja, Bus Transit, Bintuni, Efisiensi, Efektivitas.

\begin{abstract}
Public transport, in particular public transit services, is a essential facility and services provided by the government to meet the basic needs of the community. The failure of market competition in the provision of public transit services in areas that do not provide financial benefits requires local governments to fill the absence with lack of profit motives. The Bintuni government implemented the concept of bus-based transit by operating Angkutan Masyarakat Bintunu (AMB) in small urban areas with high levels of isolation and inequality, strong rural characteristics, low population, and subsistence economic conditions. Performance analysis through measuring the effectiveness and efficiency of public transport services is a very useful tool to ensure continuity and service quality improvement on a regular basis. The purpose of this study is to analyze the economic performance of $A M B$ services from the government point of view. Performance measurements are conducted to assess how effectively and efficiently financial resources are used to generate services, how the production of services is used by users, and how they impact the government. Through the method of measuring the ratios between performance components, benchmarking, and formation of composite indexes can be measured the current level of cost efficiency, service effectiveness, and cost-effectiveness, performance gap from optimum service standards, and variables that must be intervened to improve efficiency and effectiveness of $A M B$ services. The result of the study shows that the efficiency and effectiveness of $A M B$ services is still below the optimum service standard. The low financial feasibility of $A M B$ services is due to the high cost of producing transportation services that can not be matched by the revenue from the consumption of the services by users and the tariffs charged so that the $A M B$ service highly relies on government subsidies.
\end{abstract}

Kata kunci: Bus Transit, Bintuni, Efficiency, effectiveness, Performance Analysis

\section{Pendahuluan}

Transportasi umum merupakan pelayanan yang sangat penting untuk disediakan dalam rangka memenuhi kebutuhan dasar hidup masyarakat. Penyediaan transportasi umum khususnya layanan angkutan umum merupakan kewajiban dan tanggung jawab pemerintah untuk memastikan tersedianya dan terselenggaranya pelayanan angkutan umum yang selamat, aman, nyaman, dan terjangkau (Undang-Undang Nomor 22 Tahun 2009 Tentang Lalu Lintas Dan Angkutan Jalan). Pelayanan angkutan umum 
harus dapat memenuhi kebutuhan aktivitas dan mobilitas masyarakat, menjangkau seluruh lapisan wilayah dan masyarakat, secara menerus tersedia, dan memberikan manfaat ekonomi, sosial dan lingkungan.

Kegagalan pendekatan persaingan pasar dalam penyediaan layanan angkutan umum terjadi ketika pihak swasta hanya memilih wilayah atau jaringan pelayanan yang secara finansial menguntungkan dan mengabaikan wilayah atau jaringan pelayanan dengan jumlah permintaan dan tingkat penghasilan keuntungan yang rendah (Hensher, D. A., \& Gabriel, Wong, 2011). Persoalan rendahnya akses layanan angkutan umum atau tidak tersedianya layanan angkutan umum terjadi pada kawasan perdesaan dan kawasan terpencil (White, P., 2011). Penyediaan layanan angkutan umum pada kawasan ini menghadapi tantangan pada karakteristik aktivitas penduduk sangat tersebar pada wilayah yang luas dengan jarak tempuh yang jauh, dan rendahnya populasi penduduk sehingga tingkat permintaan perjalanan rendah dan tidak dapat diprediksi (Velaga, N. R., et al, 2012). Persoalan ini menuntut pemerintah mengambil alih seluruh tanggung jawab penyediaan layanan angkutan umum mulai dari perencanaan, kepemilikan infrastruktur dan sarana, sampai pada pengoperasian. Penyediaan layanan angkutan umum yang tidak berorientasi pada keuntungan pada wilayah yang tidak menguntungkan secara finansial cenderung menyebabkan pemerintah gagal beroperasi dengan efektif dan efisien (Hensher, D. A., \& Gabriel, Wong, 2011).

Kondisi permasalahan diatas terjadi pada kawasan perkotaan Bintuni di Provinsi Papua Barat. Sebagai Ibukota Kabupaten Teluk Bintuni, kawasan perkotaan ini terabaikan untuk dilayani oleh angkutan umum karena tidak memberikan kelayakan finansial bagi pelaksana angkutan. Dari sisi supply, keterisolasian dan ketimpangan wilayah, mahalnya harga komoditas, serta karakteristik kawasan yang aktivitasnya tersebar pada wilayah yang luas dan jarak tempuh yang jauh menyebabkan tingginya biaya penyediaan layanan angkutan umum. Dari sisi demand, rendahnya jumlah penduduk, dan kondisi perekonomian penduduk yang marginal dan subsisten, menyebabkan rendahnya tingkat permintaan dan kemampuan penduduk untuk melakukan perjalanan.

Kekosongan pelayanan angkutan umum ini menyebabkan permasalahan transportasi yang terjadi adalah rendahnya aksesibilitas dan mobilitas penduduk dalam mencapai fasilitas dan sarana dasar untuk pemenuhan kebutuhan hidup dan ekonomi sehari-hari, dan mahalnya biaya transportasi yang menyebabkan proporsi pengeluaran penduduk untuk transportasi menjadi sangat besar (Yayasan Pengembangan Teluk Bintuni, 2012).
Menjawab persoalan diatas, pemerintah Kabupaten Teluk Bintuni menerapkan konsep angkutan umum massal berbasis bis di kawasan perkotaan Bintuni yakni Angkutan Masyarakat Bintuni (AMB) sejak April 2015. Layanan AMB merupakan bentuk tanggung jawab pemerintah dalam melayani kebutuhan dasar seluruh lapisan masyarakat dengan memberikan kepastian pelayanan angkutan dengan harga yang terjangkau, mengurangi pengeluaran penduduk untuk transportasi, meningkatkan kesejahteraan penduduk, memacu pengembangan ekonomi wilayah, serta mengantisipasi meningkatnya penggunaan kendaraan pribadi (Yayasan Pengembangan Teluk Bintuni, 2014).

Tantangan yang dihadapi oleh pemerintah setelah AMB beroperasi adalah memastikan kelangsungan layanan. Dengan berbagai keterbatasan sumber daya, pemerintah dituntut untuk beroperasi dengan efisien dan efektif walaupun prinsip-prinsip profabilitas finansial dalam pelaksanaannya cenderung diabaikan demi memberikan pelayanan dasar kepada masyarakat.

Berdasarkan persoalan diatas maka pengukuran kinerja pelayanan melalui pengukuran efisiensi dan efektivitas menjadi hal yang penting untuk dilakukan dalam rangka memastikan kelangsungan dan meningkatkan tingkat pelayanan AMB. Studi ini bertujuan untuk menilai prestasi kerja yang telah dicapai AMB saat ini, dan mengidentifikasi faktor pelayanan yang harus diintervensi untuk mencapai target efisiensi dan efektivitas pelayanan yang lebih baik.

\section{Tinjauan Literatur}

\section{a. Konsep Dasar Pengukuran Kinerja}

Pengukuran kinerja angkutan umum dilakukan untuk mengidentifikasi tingkat pencapaian dua dimensi utama sistem angkutan yaitu efisiensi dan efektivitas (Fielding, 1978). Hubungan antara konsep efektivitas dan efisiensi dalam pengukuran kinerja dapat digambarkan dalam bentuk segitiga hubungan antara service input, service output, dan service consumption. Terdapat dua pendapat yang menggunakan konsep ini yaitu Fielding (1985) dan Giannopoulos (1989). Kedua pendapat ini menggunakan konsep Cost Efficiency, Service Effectiveness, dan Cost Effectiveness dalam pengukuran kinerja. Perbedaan dari kedua konsep ini terdapat pada pendapat Giannopoulos yang menghubungkan antara komponen kinerja dengan komunitas dimana pelayanan angkutan tersebut beroperasi. 


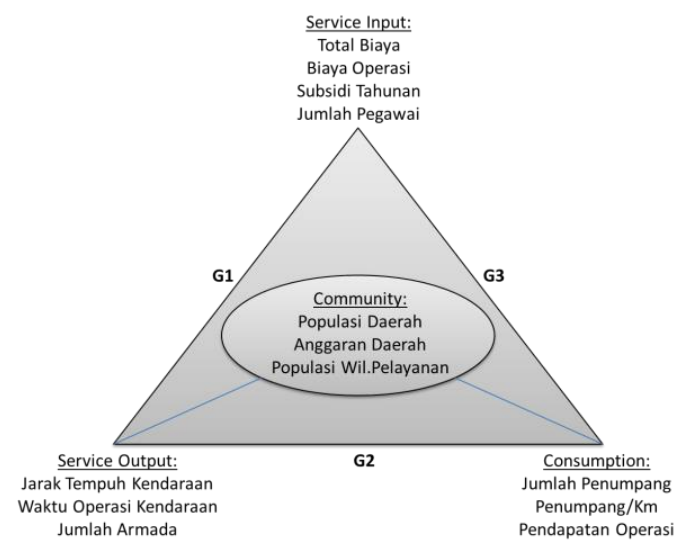

Gambar 1 Konsep Kinerja Angkutan Umum

Sumber:Giannopoulos, 1989

Keterangan:

G1: Efisiensi Biaya (Cost Efficiency) adalah konsep untuk membandingkan jumlah masukan yang telah dikeluarkan dengan jumlah keluaran yang telah dihasilkan,

G2: Efektivitas Pelayanan (Service Effectiveness) adalah konsep untuk membandingkan jumlah keluaran yang telah dipakai konsumen, dan

G3: Efektivitas Biaya (Cost Effectiveness) adalah konsep untuk membandingkan jumlah Pemakaian oleh konsumen akibat sejumlah biaya yang telah dikeluarkan.

Konsep diatas juga sejalan dengan konsep ukuran kinerja angkutan yang dipaparkan oleh Kusbiantoro (1985) dimana proses penyediaan layanan angkutan dibagi ke dalam tiga fase utama yaitu input sumber daya yang dikonversikan ke dalam pelayanan, pelayanan angkutan yang dikonversikan menjadi penumpang yang terlayani, dan penumpang yang terlayani yang berdampak pada kondisi ekonomi, sosial, dan lingkungan.

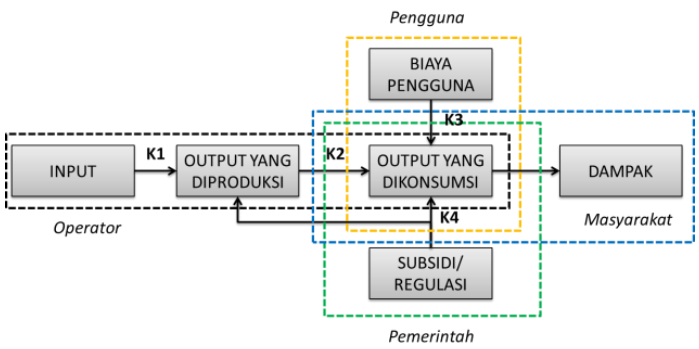

Gambar 2 Ukuran Kinerja Angkutan

Sumber: Kusbiantoro, 1985

Keterangan:

K1: Ukuran Efisiensi

K2: Ukuran Efektivitas

K3 : Ukuran Efektivitas Biaya Pengguna

K4 : Ukuran Efektivitas Subsidi/Regulasi
Berdasarkan seluruh konsep diatas maka pengukuran kinerja pelayanan difokuskan pada bagaimana dengan sumberdaya keuangan yang ada kegiatan pelayanan angkutan dihasilkan, bagaimana layanan yang dihasilkan tersebut digunakan oleh pengguna, dan bagaimana dampaknya terhadap kondisi finansial pemerintah.

\section{b. Indikator Pengukuran Kinerja}

Kinerja dapat berupa telaah terkait profitabilitas, jangkauan pelayanan, tingkat pelayanan dan kepuasan pelanggan (Sheth, 2003). Pengukuran kinerja dapat berguna untuk beberapa tujuan (Purba, 2015). Berdasarkan kerangka pengukuran kinerja diatas, diperoleh tingkat efisiensi dan efektivitas pelayanan angkutan yang dilakukan dengan membandingkan variabel antar komponen input, output, dan konsumsi. Marco Diana \& Cinzia Daraio (2010) telah merangkum indikator pengukuran kinerja angkutan umum dari berbagai sumber pada tabel 1 berikut.

Tabel 2.1 Komponen Pengukuran Kinerja Pelayanan Angkutan Umum Bis

\begin{tabular}{|c|c|}
\hline $\begin{array}{c}\text { Komponen } \\
\text { Kinerja }\end{array}$ & Variabel Kinerja \\
\hline Input & $\begin{array}{l}\text { - } \quad \text { Panjang trayek angkutan } \\
\text { - Jumlah dan gaji awak bis } \\
\text { - Jumlah dan gaji pegawai } \\
\text { - Japangan \& kantor } \\
\text { - Jumlah armada bis } \\
\text { - Jumlah subsidi Operasional } \\
\text { - } \quad \text { Jumlah biaya operasional } \\
\text { - }\end{array}$ \\
\hline Output & $\begin{array}{ll} & \text { Jumlah bis beroperasi } \\
\text { - } & \text { Waktu operasional angkutan } \\
\text { - Jumlah rit atau trip bis } \\
\text { - Jarak tempuh bis } \\
\text { - } \quad \text { Waktu tempuh bis } \\
\text { - Jumlah tempat duduk tersedia } \\
\text { - Jarak tempat duduk tersedia }\end{array}$ \\
\hline Konsumsi & $\begin{array}{ll}\text { - } & \text { Jumlah penumpang } \\
\text { - } & \text { Panjang perjalanan penumpang } \\
\text { - Jumlah tiket terjual } \\
\text { - Jumlah pendapatan dari tarif }\end{array}$ \\
\hline Komunitas & $\begin{array}{l}\text { - Jumlah Penduduk Wilayah } \\
\text { Pelayanan } \\
\text { - Luas Wilayah Pelayanan } \\
\text { - Anggaran Pemerintah }\end{array}$ \\
\hline Eksternalitas & $\begin{array}{l}\text { - Jumlah kecelakaan operasional } \\
\text { - Jumlah pengurangan trip } \\
\text { kendaraan } \\
\text { - Jumlah pengurangan jarak } \\
\text { tempuh kendaraan }\end{array}$ \\
\hline
\end{tabular}

Sumber referensi indikator kinerja angkutan yang komprehensif juga dipaparkan Florida Departement Of Transportation (2014) dalam dokumen Best Practices In Evaluating Transit Performance. Dokumen ini merangkum berbagai tinjauan terkait indikator untuk mengukur kinerja angkutan umum serta merangkum berbagai indikator kinerja dari studi kasus di berbagai 
lembaga pelaksana angkutan umum yang disajikan pada Tabel

Tabel 2.2 Indikator Kinerja Angkutan Umum

\begin{tabular}{|c|c|}
\hline Kriteria & Pengukuran \\
\hline $\begin{array}{l}\text { Pemanfaatan } \\
\text { Tenaga } \\
\text { Kerja }\end{array}$ & $\begin{array}{ll}\text { - } & \text { Gaji per kapita } \\
\text { - } & \text { Perjalanan penumpang } \\
\text { - } & \text { Jam keuntungan } \\
\text { - } & \text { Mil kendaraan per pegawai } \\
\end{array}$ \\
\hline $\begin{array}{l}\text { Efisiensi } \\
\text { Layanan }\end{array}$ & $\begin{array}{ll}\text { - } & \text { Mil keuntungan } \\
\text { - } & \text { Pengeluaran operasional } \\
\text { - } & \text { Tonsumsi energi } \\
\text { - } & \text { Mil kendaraan per galon } \\
\end{array}$ \\
\hline $\begin{array}{l}\text { Efektivitas } \\
\text { Pelayanan }\end{array}$ & $\begin{array}{ll}\text { - } & \text { Headway } \\
\text { - } & \text { Panjang rata-rata perjalanan } \\
\text { - } & \text { Ketepatan waktu } \\
\text { - } & \text { Mil kendaraan per kapita }\end{array}$ \\
\hline $\begin{array}{l}\text { Keselamatan } \\
\text { dan } \\
\text { Keamanan }\end{array}$ & $\begin{array}{ll}\text { - } & \text { Kecelakaan per } 100.000 \mathrm{mil} \\
\text { - } & \text { Tabrakan yang dapat dicegah } \\
\text { - } & \text { Total penumpang luka-luka } \\
\text { - } & \text { Total korban jiwa } \\
\end{array}$ \\
\hline $\begin{array}{l}\text { Pemanfaatan } \\
\text { kendaraan, } \\
\text { Manajemen } \\
\text { Aset, dan } \\
\text { Pernyataan } \\
\text { Perbaikan } \\
\text { Barang }\end{array}$ & $\begin{array}{ll}\text { - } & \text { Rata-rata umur armada } \\
\text { - } & \text { SGR backlog } \\
\text { - } & \text { Jumlah kegagalan system } \\
\text { - } & \text { Rasio cadangan } \\
\text { - } & \text { Total panggilan jalan } \\
\text { - Jumlah lokasi perpindaha moda } \\
\text { - } \quad \text { Persen pemberhentian yang } \\
\text { dilengkapi halte }\end{array}$ \\
\hline
\end{tabular}

Berdasarkan hasil paparan indicator yang telah disampaikan oleh Giannopoulos (1987), Kusbiantoro (1985), Marco Diana \& Cinzia Daraio (2010), dan Florida Departement Of Transportation, 2014. Didapatkan komparasi komponen kinerja pelayanan angkutan umum bis yang dapat digunakan untuk analisis sebagai berikut.

Tabel 2.3 Komparasi Komponen Pengukuran Kinerja Pelayanan Angkutan Umum Bis

\begin{tabular}{lllll}
$\begin{array}{c}\text { Komponen } \\
\text { Kinerja }\end{array}$ & $\begin{array}{c}\text { Giannop } \\
\text { oulos } \\
(\mathbf{1 9 8 7})\end{array}$ & $\begin{array}{c}\text { Kusbiant } \\
\text { oro } \\
(\mathbf{1 9 8 5 )}\end{array}$ & $\begin{array}{c}\text { Marco } \\
\text { Diana \& } \\
\text { Cinzia } \\
\text { Daraio } \\
(\mathbf{2 0 1 0 )}\end{array}$ & $\begin{array}{c}\text { Florida } \\
\text { DoT } \\
(\mathbf{2 0 1 4 )}\end{array}$ \\
\hline $\begin{array}{l}\text { Efisiensi } \\
\text { Biaya }\end{array}$ & $\mathrm{V}$ & $\mathrm{V}$ & $\mathrm{V}$ & $\mathrm{V}$ \\
\hline $\begin{array}{l}\text { Efektivitas } \\
\text { Biaya } \\
\text { Pengguna }\end{array}$ & $\mathrm{V}$ & $\mathrm{V}$ & $\mathrm{V}$ & \\
\hline $\begin{array}{l}\text { Efektivitas } \\
\text { Pelayanan }\end{array}$ & $\mathrm{V}$ & $\mathrm{V}$ & $\mathrm{V}$ & $\mathrm{V}$ \\
\hline $\begin{array}{l}\text { Efektivitas } \\
\text { Subsidi }\end{array}$ & $\mathrm{V}$ & & \\
\hline Sumber: Analisis, 2017 & & &
\end{tabular}

\section{Metodologi}

Berdasarkan konsep pengukuran kinerja angkutan umum diatas, metodologi pengukuran kinerja dilakukan melalui perhitungan dan benchmarking nilai indikator yang relevan dengan kondisi wilayah penelitian. Sehingga didapatkan ukuran efisiensi dari pelayanan angkutan umum bis AMB.

Kerstens (1996) membuktikan bahwa inefisiensi yang ditemukan dalam sistem transit berbeda secara substansial dengan metodologi estimasi, efisiensi ekonomi paling baik dilakukan pendekatan formal untuk mencapai batas produksi (Karlaftis and Tsamboulas, 2012), oleh karena itu metodologi pengukuran secara benchmarking lebih tepat karena membandingkan secara langsung indikator yang ditinjau dengan kondisi lapangan.

Pelayanan angkutan umum bis AMB terdiri dari tahapan utama yaitu pemilihan indikator kinerja efisiensi dan efektivitas pelayanan yang relevan dengan kondisi wilayah penelitian, berdasarkan komparasi komponen pengukuran kinerja pelayanan angkutan umum bis, akan digunakan 3 komponen kinerja yaitu efisiensi biaya, efektivitas biaya pengguna, efektivitas pelayanan.

Selanjutnya perhitungan dan benchmarking nilai indikator dilakukan untuk merepresentasikan tingkat efisiensi dan efektivitas pelayanan, adapun pembentukan indeks komposit kinerja digunakan untuk menilai keseluruhan kinerja dari sisi efisiensi dan efektivitas pelayanan melalui proses normalisasi dan pembobotan nilai indikator yang didapatkan dari hasil benchmarking.

Atas dasar proses diatas, didapatkan hasil kesimpulan dan rekomendasi dari analisis efisiensi dan efektivitas pelayanan AMB. Berikut disajikan alur metodologi penelitian yang telah dibahas. 


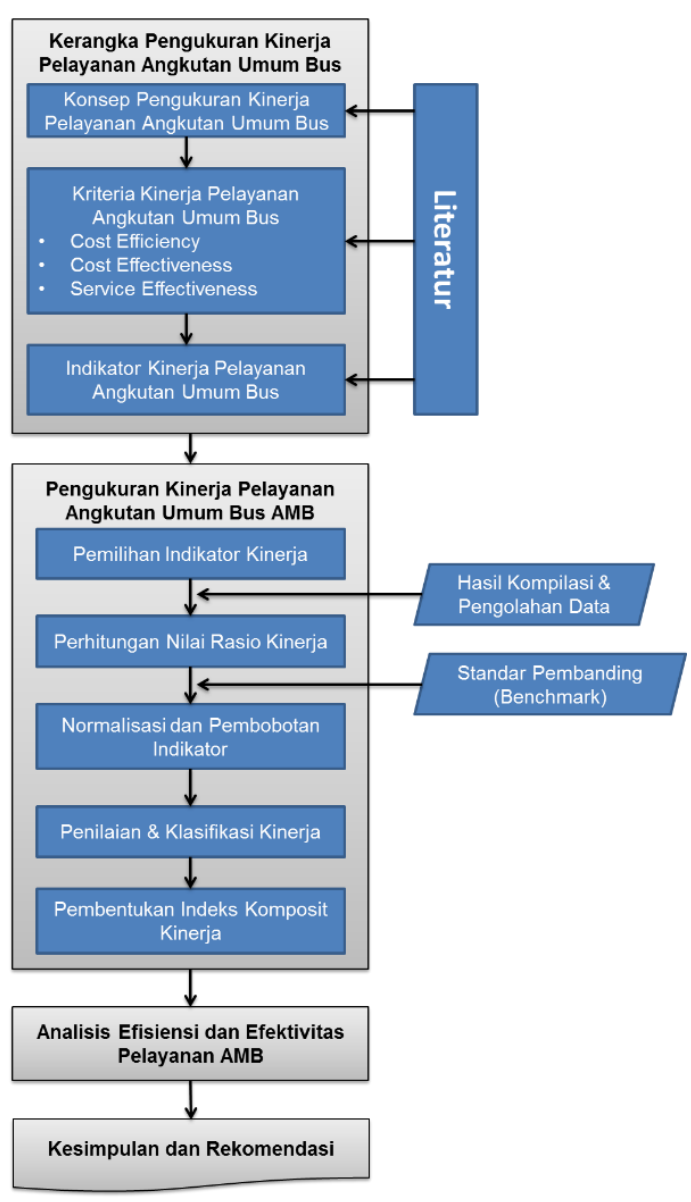

Gambar 3 Alur Metodologi Penelitian Sumber: Analisis, 2017

Pada penelitian ini komponen input, output, dan consumption yang digunakan adalah:

a. Input: Biaya operasional dan subsidi operasional. Variabel ini merupakan sumber daya keuangan yang harus disediakan oleh pemerintah untuk memproduksi layanan angkutan.

b. Output: Jumlah trip kendaraan (vehicle trip), jarak tempuh kendaraan (vehicle kilometer) dan jarak tempat duduk tersedia (available seat kilometer). Variabel ini mereprentasikan hasil produksi layanan dari penggunaan sumber daya keuangan.

c. Consumption: Panjang perjalanan penumpang dalam sistem angkutan (passengers kilometer) dan pendapatan operasional dari tarif (revenue). Variabel ini mereprentasikan tingkat konsumsi layanan dari pelayanan yang telah diproduksi.

Berdasarkan variabel diatas maka indikator penilaian kinerja dari sisi efisiensi dan efektivitas yang dipilih ditampilkan pada tabel 4 berikut.
Tabel 3.1 Indikator Pengukuran Kinerja Pelayanan AMB

\begin{tabular}{|c|c|c|}
\hline Kriteria & Indikator & Satuan \\
\hline \multirow{2}{*}{$\begin{array}{l}\text { Cost } \\
\text { Efficiency } \\
\text { (CEF) }\end{array}$} & $\begin{array}{l}\text { Biaya Operasional / } \\
\text { Trip Kendaraan }\end{array}$ & $\begin{array}{l}\mathrm{Rp} / \\
\text { Kend-Trip }\end{array}$ \\
\hline & $\begin{array}{l}\text { Subsidi Operasional / } \\
\text { Trip Kendaraan }\end{array}$ & $\begin{array}{l}\mathrm{Rp} / \\
\text { Kend-Trip }\end{array}$ \\
\hline \multirow{3}{*}{$\begin{array}{l}\text { Cost } \\
\text { Effectiveness } \\
(\mathrm{CEV})\end{array}$} & $\begin{array}{l}\text { Biaya Operasional / } \\
\text { Jarak Tempuh } \\
\text { Penumpang }\end{array}$ & $\begin{array}{l}\mathrm{Rp} / \mathrm{Pnp}- \\
\mathrm{Km}\end{array}$ \\
\hline & $\begin{array}{l}\text { Subsidi Operasional / } \\
\text { Jarak Tempuh } \\
\text { Penumpang }\end{array}$ & $\begin{array}{l}\mathrm{Rp} / \mathrm{Pnp}- \\
\mathrm{Km}\end{array}$ \\
\hline & $\begin{array}{l}\text { Pendapatan } \\
\text { Operasional / Biaya } \\
\text { Operasional }\end{array}$ & $\%$ \\
\hline \multirow{2}{*}{$\begin{array}{l}\text { Service } \\
\text { Effectiveness } \\
\text { (SEV) }\end{array}$} & $\begin{array}{l}\text { Pendapatan } \\
\text { Operasional/ Jarak } \\
\text { Tempuh Kendaraan }\end{array}$ & $\begin{array}{l}\text { Pnp-Km / } \\
\text { Kend-Km }\end{array}$ \\
\hline & $\begin{array}{l}\text { Jarak Tempuh } \\
\text { Penumpang / Jarak } \\
\text { Tempat Duduk } \\
\text { Tersedia }\end{array}$ & $\begin{array}{l}\text { Pnp-Km / } \\
\text { Seat-Km }\end{array}$ \\
\hline
\end{tabular}

Sumber: Analisis 2017

Untuk menilai tingkat kinerja angkutan AMB maka dilakukan benchmarking dengan pelayanan angkutan umum bis perkotaan yang memiliki tingkat kinerja pelayanan yang jauh lebih mapan. Nilai indikator kinerja kedua trayek AMB dibandingkan dengan nilai kinerja trayek angkutan perkotaan bis DAMRI di kawasan perkotaan Bandung yaitu trayek CicaheumCibereum. Angkutan dan trayek ini dipilih karena dari sisi ekonomi pengoperasian angkutan bis perkotaan DAMRI telah menunjukkan kelayakan finansial yang baik. Pada tahun 2014 Trayek Cicahuem-Cibeureum menunjukkan kondisi finansial pelayanan yang cukup baik dimana tingkat pendapatan operasional mencapai $82,52 \%$ dari total biaya operasional (Zuriyati, 2015).

Nilai indikator yang dinormalisasi akan memiliki rentang nilai antara 0 sampai dengan 1 dimana sistem yang memiliki kinerja tertinggi akan memiliki skor 1. Rumus yang digunakan untuk perhitungan nilai utilitas terdiri dari dua jenis yaitu untuk indikator yang memiliki dampak positif dan untuk indikator yang memiliki dampak negatif. Berikut rumus teknik utilitas yang digunakan:

- Indikator dengan dampak positif

$$
n_{i}=\frac{x_{i}}{\operatorname{Max}(\text { Semua } x)}
$$

- Indikator dengan dampak negatif

$$
n_{i}=\frac{\operatorname{Min}(\operatorname{Semua} x)}{x_{i}}
$$

Untuk menghitung nilai keseluruhan indeks kinerja efisiensi dan efektivitas pelayanan maka dilakukan pembobotan terhadap setiap indikator di masing-masing kriteria kinerja dan trayek. Nilai 
bobot yang digunakan akan dibagi secara merata sesuai dengan jumlah indikator di setiap kriteria kinerja. Penjumlahan nilai seluruh indikator di setiap kriteria akan menghasilkan indeks komposit cost efficiency, cost effectiveness, dan service effectiveness.

Tahapan terakhir pada penelitian ini adalah dengan menganalisis lebih dalam tingkat efisiensi dan efektivitas pelayanan angkutan AMB berdasarkan keterkaitan antar faktor atau variabel yang mempengaruhi. Hasil pembahsan ini menjadi dasar dalam menentukan bentuk intervensi terhadap veriabel tersebut dalam rangka meningkatkan kinerja efisiensi dan efektivitas pelayanan yang lebih baik.

\section{Karakteristik Pelayanan AMB}

\section{a. Karakteristik Wilayah Pelayanan AMB}

Kawasan perkotaan Bintuni secara administratif berada di Distrik Bintuni dan Distrik Manimeri. Penggunaan lahan di Distrik Bintuni dan Manimeri didominasi oleh kawasan hutan. Kawasan terbangun pada hanya sebesar
$2.475,77 \mathrm{Ha}$ atau $3,35 \%$ dari total luas wilayah administrasi kedua distrik.

Aktivitas penduduk di kawasan perkotaan Bintuni hanya terkonsentrasi di sekitar Jalan Nasional Bintuni-Manimeri sepanjang 42 Km (Kompi E Komplek Perkantoran Pemerintah Kabupaten Teluk Bintuni). Perkembangan kawasan perkotaan Bintuni sangat linear di sepanjang jalan ini. Deliniasi wilayah Kawasan Perkotaan Bintuni dapat dilihat pada Gambar 4.

Kawasan perkotaan di Distrik Bintuni merupakan kawasan perkotaan yang lebih awal terbentuk sehingga konsentrasi aktivitas penduduk dan fasilitas perkotaan terdapat pada distrik ini. Distrik Manimeri merupakan kawasan perluasan perkotaan Distrik Bintuni.

Jumlah penduduk di kawasan perkotaan Bintuni adalah sebesar 28.106 pada tahun 2016. Aktivitas utama Distrik Manimeri adalah kawasan transmigrasi, pertanian dan perkebunan, serta Kompleks Perkantoran Pemda Kabupaten Teluk Bintuni. Jumlah dan kepadatan penduduk di kawasan perkotaan Bintuni sangat rendah. Menurut luas kawasan terbangunnya, kepadatan

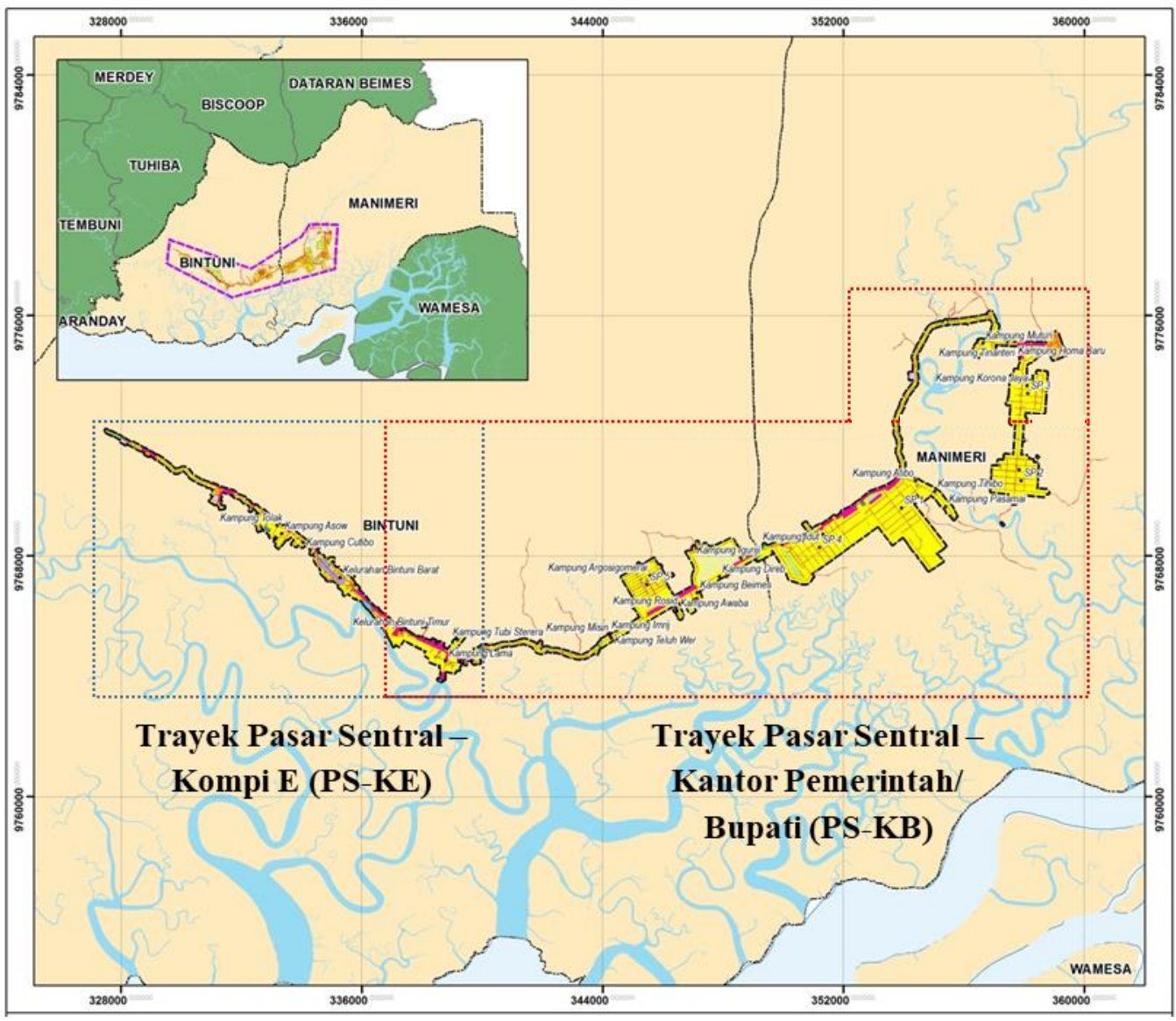

Gambar 4. Peta Kawasan Perkotaan Bintuni dan Wilayah Pelayanan Trayek

Sumber: Analsis, 2017 
penduduk hanya 22,71 Jiwa/Ha di Distrik Bintuni dan 3,78 Jiwa/Ha di Distrik Manimeri.

Tingkat kesejahteraan penduduk di wilayah perkotaan Bintuni masih tergolong rendah yang ditunjukkan dari tingkat pendapatan perkapita yang rendah, tingginya nilai indeks kedalaman dan keparahan kemiskinan, dan proporsi penduduk miskin yang cukup besar. Harga komoditas khususnya harga BBM di kawasan perkotaan Bintuni sangat tinggi dan diperparah dengan ketersediaan atau pasokan yang sangat terbatas.

Pergerakan penduduk di kawasan perkotaan Bintuni hanya bertumpu pada angkutan roda dua atau ojek karena tidak terdapat pilihan alternatif angkutan umum lainnya walaupun tarif ojek tergolong sangat mahal. Rendahnya pendapatan masyarakat dan tingginya biaya transportasi menyebabkan proporsi alokasi pendapatan individu untuk sektor transporasi mencapai 25 $35 \%$ dari total pendapatan per bulan atau antara Rp. 289.236 - Rp. 404.930 per bulan (Yayasan Pengembangan Teluk Bintuni, 2014).

\section{b. Karakteristik Pengoperasian AMB}

Dengan semakin meningkatnya keuangan daerah dan dengan bantuan dana CSR dari British Petroleum (BP) Berau Ltd., Pemda Kabupaten Teluk Bintuni menerapkan konsep angkutan umum massal berbasis bis di kawasan perkotaan Bintuni yakni Angkutan Masyarakat Bintuni (AMB). AMB dioperasikan dibawah tanggung jawab Dinas Perhubungan, Komunikasi, dan Informatika (Dishubkominfo) dan Unit Pelaksana Teknis (UPT AMB) sebagai pelaksana teknis.

AMB beroperasi dengan dua trayek utama yaitu Trayek Pasar Sental - Kompi E (trayek PS - KE) dengan wilayah pelayanan di internal Distrik Bintuni dan Trayek Pasar Sentral - Kantor Bupati (Trayek PS - KB) dengan wilayah pelayanan yang menghubungkan antara Distrik Bintuni dengan Distrik Manimeri. Keseluruhan karakteristik pengoperasian layanan angkutan AMB dipaparkan pada Tabel 5.

Tabel 3.2 Karakteristik Pelayanan Operasional AMB

\begin{tabular}{|c|c|c|}
\hline Hasil Pengolahan Data & Trayek PS - KE & Trayek PS - KB \\
\hline Panjang Trayek & $12,5 \mathrm{Km}$ & $30 \mathrm{Km}$ \\
\hline Halte dan Bus stop & $\begin{array}{l}22 \text { Halte } \\
\text { Jarak antar halte } 582,93 \text { meter }\end{array}$ & $\begin{array}{l}32 \text { Halte } \\
\text { Jarak antar halte } 950,44 \text { meter }\end{array}$ \\
\hline Karakteristik Armada Bis & \multicolumn{2}{|c|}{10 Bis = Kapasitas Tempat Duduk 27 Seat + Max 20 Berdiri } \\
\hline Bus Siap Operasi & $\begin{array}{l}\text { Senin }- \text { Jumat }=2 \text { Bis } \\
\text { Sabtu }=1 \text { Bis } \\
\text { Minggu }=1 \text { Bis }\end{array}$ & $\begin{array}{l}\text { Senin }- \text { Jumat }=4 \text { Bis } \\
\text { Sabtu }=3 \text { Bis } \\
\text { Minggu }=2 \text { Bis }\end{array}$ \\
\hline Headway & $\begin{array}{l}\text { Senin }- \text { Jumat }=30 \text { menit } \\
\text { Sabtu }=60 \text { Menit } \\
\text { Minggu }=60 \text { Menit }\end{array}$ & $\begin{array}{l}\text { Senin }- \text { Jumat }=30 \text { menit } \\
\text { Sabtu }=40 \text { Menit } \\
\text { Minggu }=60 \text { Menit }\end{array}$ \\
\hline Jumlah Trip Kendaraan & $\begin{array}{l}\text { - } 16 \text { trip per bis per hari } \\
\text { - } 711 \text { Trip/Bulan }\end{array}$ & $\begin{array}{l}12 \text { trip per bis per hari } \\
\text { - } 1.090 \text { Trip/Bulan }\end{array}$ \\
\hline Jarak Tempuh Kendaraan & $9.187,29 \mathrm{Km} /$ Bulan & 43.127,21 Km/Bulan \\
\hline Jarak Tempat Duduk Tersedia & $248.056,71$ Seat-Km/Bulan & 1.164.434,79 seat-Km/Bulan \\
\hline Konsumsi BBM & 2.003,91 Liter /Bulan & 9.403,23 Liter/Bulan \\
\hline Biaya Operasional Kendaraan & Rp. $7.422,58 / \mathrm{Km}$ & Rp. 6.099,68/Km. \\
\hline Biaya Operasional & Rp. 68.193.390,27/Bulan & 263.062.122,23/Bulan \\
\hline Tarif & $\begin{array}{l}\text { Umum Rp. } 5.000 \\
\text { Pelajar Rp. } 3.000 .\end{array}$ & $\begin{array}{l}\text { Umum Rp. } 10.000 \\
\text { Pelajar Rp. } 5.000 .\end{array}$ \\
\hline Jumlah Trip Penumpang & $\begin{array}{l}\text { - } 3.292 \text { trip } \\
\text { - } 84,16 \% \text { Umum } \\
\text { - } 15,84 \% \text { Pelajar } \\
\end{array}$ & $\begin{array}{l}\text { - } 13.146 \text { trip } \\
\text { - } 76,94 \% \text { Umum } \\
\text { - } 23,06 \% \text { Pelajar } \\
\end{array}$ \\
\hline Jarak Tempuh Penumpang & $\begin{array}{l}\text { - 55,46 Pnp-Km/trip Kend } \\
\text { - } 6,68 \mathrm{Km} / \mathrm{Pnp}\end{array}$ & $\begin{array}{l}\text { - 352,95 Pnp-Km/trip Kend. } \\
\text { - 21,92 Km/Pnp }\end{array}$ \\
\hline Pendapatan Operasional & Rp. 15.419.000/Bulan & 116.297.000/Bulan \\
\hline Subsidi Operasional & RP. 52.774.390,27/Bulan & Rp. 146.765.122,23/Bulan \\
\hline
\end{tabular}

\section{Pengukuran Kinerja Efisiensi dan Efektivitas Pelayanan AMB}

Berdasarkan indikator yang telah terpilih dan data pengoperasian AMB, maka dilakukan perhitungan nilai untuk setiap indikator. Nilai setiap indikator untuk kedua trayek AMB dibandingkan dengan nilai benchmark. Pada studi ini standarisasi (benchmarking) dilakukan dengan membandingkan kinerja trayek PS - KE dan trayek PS - KB dengan dengan trayek Damri di Kota Bandung yaitu Rute Cicaheum Cibeureum AC. Kondisi kinerja untuk setiap indikator dan trayek diilustrasikan pada Tabel 6 dan Gambar 5.

Tabel 3.3 Pengukuran dan Normalisasi Nilai Indikator Kinerja AMB

\begin{tabular}{lccc} 
Indikator & $\begin{array}{c}\text { Trayek } \\
\text { PS - KE }\end{array}$ & $\begin{array}{c}\text { Trayek } \\
\text { PS - KB }\end{array}$ & Benchmark \\
\hline \multicolumn{4}{c}{ Rekapitulasi Nilai Indikator } \\
\hline CEF1 & $95.902,31$ & $189.829,51$ & $137.823,28$
\end{tabular}




\begin{tabular}{lrrr} 
CEF2 & $74.218,13$ & $83.190,92$ & $20.233,96$ \\
\hline SEV1 & $1.678,30$ & $3.426,55$ & $8.710,32$ \\
\hline SEV2 & 0,16 & 0,42 & 0,62 \\
\hline CEV1 & $1.729,22$ & 537,84 & 274,51 \\
\hline CEV2 & $1.338,23$ & 235,70 & 40,30 \\
\hline CEV3 & 0,23 & 0,56 & 0,85 \\
Sumber: Analisis 2017 & &
\end{tabular}

Sumber: Analisis 2017

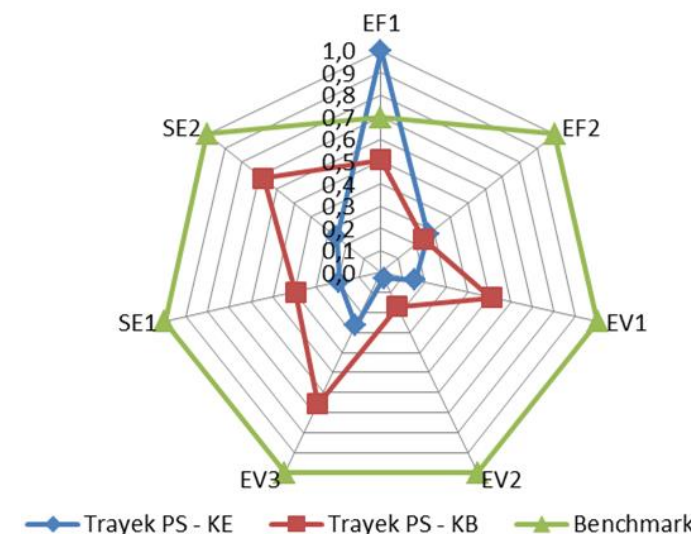

Gambar 5. Diagram Kinerja Indikator Sumber: Analisis, 2017

Seluruh nilai indikator selanjutnya dilakukan normalisasi untuk menjustifikasi tingkat kinerja efisiensi dan efektivitas pelayanan (Tabel 7).

Tabel 3.4 Pengukuran dan Normalisasi Nilai Indikator Kinerja AMB

\begin{tabular}{lccr} 
Indikator & $\begin{array}{c}\text { Trayek } \\
\text { PS - KE }\end{array}$ & $\begin{array}{c}\text { Trayek } \\
\text { PS - KB }\end{array}$ & Benchmark \\
\hline \multicolumn{4}{c}{ Normalisasi Nilai Indikator } \\
\hline CEF1 & 1,00 & 0,51 & 0,70 \\
\hline CEF1 & 0,27 & 0,24 & 1,00 \\
\hline SEV1 & 0,19 & 0,39 & 1,00 \\
\hline SEV2 & 0,26 & 0,68 & 1,00 \\
\hline CEV1 & 0,16 & 0,51 & 1,00 \\
\hline CEV2 & 0,03 & 0,17 & 1,00 \\
\hline CEV3 & 0,27 & 0,66 & 1,00 \\
Sumber: Analisis 2017 & &
\end{tabular}

Berdasarkan hasil perhitungan diatas maka dapat dianalisis tingkat kinerja untuk setiap indikator berdasarkan tinjauan literatur (Giannopoulus, 1987; Kusbiantoro, 1985; Marco Diana \& Cinzia Daraio, 2010; Florida DoT, 2014) sebagai berikut:

a. Biaya Operasional/ Trip Kendaraan (CEF1) Indikator ini merepresentasikan tingkat efisiensi biaya (cost efficiency). Sebagai salah satu indikator input, indikator ini mengukur seberapa besar penggunaan sumber daya keuangan dalam pengoperasian bis (Giannopoulus, 1987; Kusbiantoro, 1985; Marco Diana \& Cinzia Daraio, 2010; Florida DoT, 2014).

Indikator ini merupakan indikator dengan dampak negatif dimana semakin kecil nilai rasio menunjukkan semakin sedikit sumber daya keuangan yang harus ditanggung pemerintah untuk setiap produksi trip kendaraan.

Trayek PS-KE memiliki kinerja efisiensi biaya yang lebih baik dibandingkan trayek PS-KB dan benchmark sedangkan kinerja trayek PS$\mathrm{KB}$ lebih rendah dibandingkan dengan benchmark. Hal ini dikarenakan jarak tempuh trayek yang lebih jauh walaupun biaya operasional per kilometer trayek ini lebih kecil dibandingkan trayek PS - KE.

b. Subsidi Operasional / Trip Kendaraan (CEF2) Indikator ini merepresentasikan tingkat efisiensi biaya (cost efficiency). Sebagai salah satu indikator input khususnya input dari pemerintah, indikator ini mengukur seberapa besar sumber daya keuangan yang harus ditanggung pemerintah diluar biaya operasional yang terbayar oleh pendapatan operasional (Giannopoulus, 1987; Kusbiantoro, 1985)

Indikator ini merupakan indikator dengan dampak negatif dimana semakin kecil nilai rasio menunjukkan semakin sedikit tambahan sumber daya keuangan yang harus ditanggung pemerintah untuk menutupi kerugian setiap produksi trip kendaraan.

Kedua trayek AMB memiliki kinerja yang lebih rendah dibandingkan dengan nilai benchmark. Trayek PS - KE memiliki kinerja yang lebih baik dibandingkan trayek PS - KB karena subsidi yang dibutuhkan lebih rendah untuk setiap trip kendaraan.

c. Pendapatan Operasional/ Jarak Tempuh Kendaraan (SEV1)

Indikator ini merepresentasikan tingkat kinerja dari sisi efektivitas pelayanan (service effectiveness). Sebagai salah satu indikator output, indikator ini mengukur tingkat kemampuan layanan menghasilkan keuntungan (revenue generation) yakni seberapa besar pendapatan dari tarif yang dapat dihasilkan dari setiap kilometer tempuh kendaraan yang diproduksi (Marco Diana \& Cinzia Daraio, 2010).

Indikator ini merupakan indikator dengan dampak positif dimana semakin besar nilai rasio menunjukkan tingkat penghasilan pendapatan dan efektivitas pelayanan yang lebih baik.

Kedua trayek AMB memiliki kinerja yang lebih rendah dibandingkan dengan nilai benchmark. Trayek PS-KB memiliki tingkat efektivitas pelayanan yang lebih baik dibandingkan trayek PS-KE karena produksi layanan lebih banyak dikonsumsi oleh penumpang dan dapat menghasilkan pendapatan dari tarif yang lebih besar.

d. Jarak Tepuh Penumpang / Jarak Tempat Duduk Tersedia (SEV2) 
Indikator ini merepresentasikan tingkat kinerja dari sisi efektivitas pelayanan (service effectiveness). Sebagai salah satu indikator output, indikator ini mengukur tingkat intensitas penggunaan layanan berupa faktor muat penumpang (Passenger Load Factor) yaitu kapasitas yang dikonsumsi penumpang terhadap kapasitas yang ditawarkan (Giannopoulus, 1987; Kusbiantoro, 1985; Marco Diana \& Cinzia Daraio, 2010; Florida DoT, 2014)..

Indikator ini merupakan indikator dengan dampak positif dimana semakin besar nilai rasio menunjukkan tingkat efektivitas pelayanan dan tingkat intensitas penggunaan layanan angkutan yang lebih baik.

Kedua trayek AMB memiliki kinerja yang lebih rendah dibandingkan dengan nilai benchmark. Trayek PS - KB memiliki tingkat efektivitas pelayanan yang lebih baik dibandingkan trayek PS - KE karena memiliki penggunaan kapasitas layanan yang lebih besar.

Passenger load factor untuk trayek PS - KE sebesar $15,90 \%$, dan trayek PS - KB sebesar $42,02 \%$. Nilai passengers load factor kedua trayek masih tergolong rendah dibandingkan dengan standar yang ditetapkan Keputusan Direktur Jenderal Perhubungan Darat Nomor: SK.687/AJ.206/DRJD/2002 sebesar 70\%.

e. Biaya Operasional / Jarak Tempuh Penumpang (CEV1)

Indikator ini merepresentasikan tingkat efektivitas biaya (cost effectiveness). Sebagai salah satu indikator input, indikator ini mengukur besarnya biaya operasi bis per jarak tempuh penumpang. (Giannopoulus, 1987; Kusbiantoro, 1985; Marco Diana \& Cinzia Daraio, 2010; Florida DoT, 2014).

Indikator ini adalah indikator dengan dampak negatif dimana semakin kecil nilai rasio menunjukkan tingkat efektivitas biaya yang lebih baik karena semakin sedikit sumber daya keuangan yang harus disediakan pemerintah untuk setiap kilometer jarak yang ditempuh penumpang dalam sistem angkutan.

Kedua trayek AMB memiliki kinerja yang lebih rendah dibandingkan dengan benchmark. Trayek PS-KB memiliki kinerja yang lebih baik dibandingkan trayek PS-KE karena membutuhkan biaya operasional angkutan yang lebih rendah untuk setiap kilometer jarak yang ditempuh penumpang dalam sistem angkutan. Hal ini dikarenakan jumlah penumpang trayek ini lebih banyak dan ratarata panjang perjalanan penumpang yang lebih besar mengingat jarak tempuh trayek yang jauh. f. Subsidi Operasional / Jarak Tempuh Penumpang (CEV2)

Indikator ini merepresentasikan tingkat efektivitas biaya (cost effectiveness). Sebagai salah satu indikator input khususnya input dari pemerintah, indikator ini mengukur seberapa besar biaya yang harus ditanggung pemerintah per jarak tempuh penumpang (Giannopoulus, 1987; Kusbiantoro, 1985).

Indikator ini merupakan indikator dengan dampak negatif dimana semakin kecil nilai rasio maka semakin sedikit sumber daya keuangan tambahan yang harus ditanggung pemerintah untuk menutupi kerugian dari setiap kilometer jarak yang ditempuh penumpang dalam sistem angkutan.

Kedua trayek AMB memiliki kinerja yang lebih rendah dibandingkan dengan nilai benchmark. Trayek PS-KB memiliki kinerja yang lebih baik dibandingkan trayek PS-KE karena subsidi yang dibutuhkan lebih rendah untuk setiap kilometer jarak tempuh penumpang dalam sistem angkutan. Hal ini dikarenakan jumlah penumpang trayek ini lebih banyak dan rata-rata panjang perjalanan penumpang yang lebih besar mengingat jarak tempuh trayek yang jauh.

g. Pendapatan Operasional / Biaya Operasional (CEV3)

Indikator ini merepresentasikan tingkat efektivitas biaya (cost effectiveness). Sebagai salah satu indikator output, indikator menilai tingkat pengembalian biaya operasional dari pendapatan operasional (cost recovery). Sehingga nantinya didapatkan informasi keuntungan atau subsidi yang perlu ditanggung oleh pemerintah (Marco Diana \& Cinzia Daraio, 2010).

Indikator ini merupakan indikator dengan dampak positif dimana semakin besar nilai rasio menunjukkan tingkat efektivitas biaya dan cost recovery yang lebih baik.

Kedua trayek AMB memiliki kinerja yang lebih rendah dibandingkan dengan nilai benchmark. Rasio cost recovery trayek PS KE hanya sebesar $22,61 \%$, dan trayek PS KB sebesar $56,18 \%$. Trayek PS - KB memiliki kinerja yang lebih baik dibandingkan trayek PS - KE karena menunjukkan tingkat cost recovery yang lebih tinggi. Rendahnya tingkat cost recovery pada trayek PS - KE dikarenakan masih rendahnya jumlah penumpang dan tingkat tarif yang dibebankan.

Berdasarkan analisis menggunakan diagram kinerja indikator, didapatkan bahwa nilai dari indikator benchmark cenderung lebih besar dari nilai Trayek PS-KB dan Trayek PS-KE.

Untuk memperoleh gambaran keseluruhan kinerja dari sisi efisiensi dan efektivitas maka 
dilakukan perhitungan indeks komposit kinerja melalui pembobotan setiap indikator di masingmasing kriteria kinerja.

Dengan menggunakan proporsi yang sama untuk setiap indikator di masing-masing kriteria kinerja maka bobot yang digunakan adalah sebesar 0,5 untuk kriteria cost efficiency, 0,33 untuk kriteria cost effectiveness, dan 0,5 untuk kriteria cost efficiency maka diperoleh indeks komposit kinerja seperti yang ditunjukkan pada Tabel 7 dan diilustrasikan pada Gambar 6.

Tabel 3.5 Indeks Komposit Kinerja Efisiensi dan Efektivitas

\begin{tabular}{cccc} 
Trayek & $\begin{array}{c}\text { Index } \\
\text { CEF }\end{array}$ & $\begin{array}{c}\text { Index } \\
\text { CEV }\end{array}$ & $\begin{array}{c}\text { Index } \\
\text { SEV }\end{array}$ \\
\hline Trayek PS - KE & 0,64 & 0,15 & 0,23 \\
\hline Trayek PS - KB & 0,37 & 0,45 & 0,54 \\
\hline Benchmark & 0,85 & 1,00 & 1,00
\end{tabular}

Sumber: Analisis, 2017

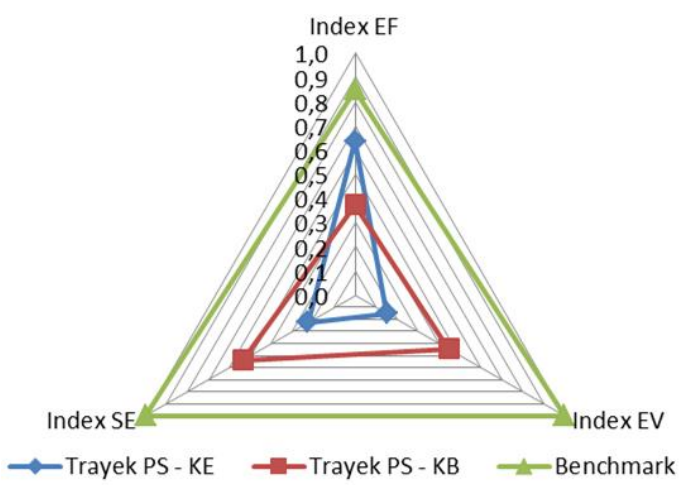

Gambar 6 Diagram Indeks Komposit Kinerja

Sumber: Analisis, 2017

Diagram diatas menunjukkan tingkat kinerja efisiensi dan efektivitas pelayanan AMB masih di bawah benchmark sebagai standar pelayanan yang baik. Jika dibandingkan antara kedua trayek $\mathrm{AMB}$, trayek PS - KE memiliki tingkat kinerja efisiensi biaya yang lebih baik karena biaya operasional dan subsidi operasional yang lebih kecil untuk setiap trip kendaraan yang diproduksi. Namun kinerja efisiensi biaya yang lebih baik ini tidak diikuti dengan tingkat penggunaan layanan yang tinggi sehingga untuk kinerja efektivitas pelayanan dan efektivitas biaya pada trayek ini masih rendah. Rendahnya penggunaan layanan pada trayek ini disebabkan oleh persaingan dengan angkutan ojek di wilayah pelayanan. Masyarakat lebih memilih menggunakan ojek untuk perjalanan dengan jarak pendek karena ketersediaan ojek lebih banyak sehingga lebih dapat diandalkan dengan tarif yang tidak jauh berbeda dengan tarif yang ditetapkan AMB.

Trayek PS - KB memiliki tingkat kinerja efektivitas pelayanan dan efektivitas biaya yang lebih baik karena jumlah pengguna trayek yang lebih banyak dan tarif angkutan yang lebih tinggi. Walaupun efisiensi biaya untuk memproduksi layanan tergolong rendah namun konsumsi layanan oleh pengguna dan pendapatan dari tarif yang dibayarkan dapat mengimbangi biaya tersebut. Lebih tingginya penggunaan layanan pada trayek ini dikarenakan rendahnya ketersediaan ojek pada wilayah pelayanan trayek ini sehingga masyarakat sangat mengandalkan pelayanan trayek ini.

\section{Diskusi}

\section{a. Komponen Biaya Operasional} Kendaraan (BOK)

Diketahui bahwa biaya operasional kedua trayek AMB sangat tinggi dengan tingkat efisiensi biaya dan efektivitas biaya yang rendah. Berdasarkan perhitungan BOK (Tabel 5), diketahui bahwa proporsi terbesar BOK adalah dari komponen BBM yakni sebesar $32,33 \%$ pada trayek PS-KE dan sebesar $39,35 \%$ pada trayek PS-KB. Tingginya biaya BBM di Bintuni disebabkan oleh mahalnya harga solar yang mencapai $\mathrm{Rp}$. 12.000/liter dan sangat jauh berbeda dibandingkan dengan harga yang ditetapkan secara nasional yaitu sebesar Rp 5.150 per liter (per April 2016).

Tabel 4.1 Proporsi Komponen Biaya Operasional Kendaraan (BOK)

\begin{tabular}{|c|c|c|}
\hline \multirow{2}{*}{ Komponen BOK } & $\begin{array}{l}\text { Trayek } \\
\text { PS-KE }\end{array}$ & $\begin{array}{l}\text { Trayek } \\
\text { PS-KB } \\
\end{array}$ \\
\hline & $\%$ & $\%$ \\
\hline Biaya penyusutan & $0,75 \%$ & $0,49 \%$ \\
\hline Biaya awak bus & $34,46 \%$ & $22,43 \%$ \\
\hline Biaya BBM & $32,33 \%$ & $39,35 \%$ \\
\hline Biaya ban & $8,08 \%$ & $9,84 \%$ \\
\hline $\begin{array}{l}\text { Biaya pemeliharaan } \\
\text { kendaraan }\end{array}$ & $16,41 \%$ & $16,22 \%$ \\
\hline STNK & $3,78 \%$ & $2,46 \%$ \\
\hline Biaya KIR bus & $0,02 \%$ & $0,01 \%$ \\
\hline Biaya pemeliharaan AC & $0,17 \%$ & $0,11 \%$ \\
\hline Biaya Langsung & 96,00 & 90,91 \\
\hline Biaya Tidak Langsung & $4,00 \%$ & $9,09 \%$ \\
\hline Total & $100 \%$ & $100 \%$ \\
\hline
\end{tabular}

Sumber: Analisis, 2017

Komitmen pemerintah daerah untuk menstabilkan harga BBM untuk pelayanan dan pengoperasian AMB maka akan berdampak besar pada pengurangan biaya operasional AMB. Dengan menggunakan harga BBM sebesar Rp 5.150/liter maka akan meningkatkan kinerja efisiensi dan efektivitas biaya karena biaya operasional dan subsidi operasional akan berkurang.

Pada trayek PS - KE biaya operasional per jarak tempuh kendaraan menurun dari Rp. 7.422,58 menjadi Rp. 6.052,57 atau berkurang 22,64\% dengan proporsi komponen harga BBM 
berkurang sebesar $15,32 \%$ dari $32,33 \%$ menjadi $17,02 \%$. Pada trayek PS - KB penurunan terjadi dari Rp. 6.099,68 menjadi Rp. 4.729,68 atau berkurang 28,97\% dengan proporsi komponen harga BBM berkurang sebesar $17,57 \%$ dari $39,35 \%$ menjadi $21,78 \%$. Tingkat cost recovery untuk trayek PS - KE meningkat dari $22,61 \%$ menjadi $27,73 \%$ dan untuk trayek PS - KB meningkat dari $56,18 \%$ menjadi $72,45 \%$. Perhitungan penurunan biaya operasional dan subsdi operasional dengan skenario pengurangan biaya BBM dapat dilihat pada Tabel 9.

Tabel 4.2 Pengurangan Biaya Operasional Melalui Pengurangan Biaya BBM

\begin{tabular}{lcc}
\multicolumn{3}{c}{ Melalui Pengurangan Biaya BBM } \\
& $\begin{array}{c}\text { Trayek } \\
\text { PS - KE }\end{array}$ & $\begin{array}{c}\text { Trayek } \\
\text { PS - KB }\end{array}$ \\
\hline \multicolumn{3}{c}{ Biaya Operasional } \\
\hline $\begin{array}{l}\text { Rata-rata Biaya } \\
\text { Operasional per Bulan }\end{array}$ & 68.193 .390 & 207.022 .637 \\
\hline $\begin{array}{l}\text { Rata-rata Biaya } \\
\text { Operasional per Bulan } \\
\text { (skenario pengurangan } \\
\text { biaya BBM) }\end{array}$ & 55.606 .690 & 160.525 .001 \\
\hline $\begin{array}{l}\text { Pengurangan } \\
\text { Biaya Operasional }\end{array}$ & 12.586 .700 & 46.497 .636 \\
\hline $\begin{array}{l}\text { Proporsi pengurangan } \\
\text { Biaya Operasional }\end{array}$ & $22,64 \%$ \\
\hline \multicolumn{3}{c}{ Subsidi Operasional } \\
\hline $\begin{array}{l}\text { Rata-rata Subsidi } \\
\text { Operasional per Bulan }\end{array}$ & 738.841 .464 & 1.270 .158 .921 \\
\hline $\begin{array}{l}\text { Rata-rata Subsidi } \\
\text { Operasional per Bulan } \\
\text { (skenario pengurangan } \\
\text { biaya BBM) }\end{array}$ & 562.627 .659 & 619.192 .019 \\
\hline $\begin{array}{l}\text { Pengurangan } \\
\text { Subsidi Operasional }\end{array}$ & 176.213 .805 & 650.966 .902 \\
\hline $\begin{array}{l}\text { Proporsi pengurangan } \\
\text { Subsidi Operasional } \\
\text { Sumber: Analisis, 2017 }\end{array}$ & $31,32 \%$ & $105,13 \%$ \\
\hline
\end{tabular}

b. Tingkat Tarif, Pendapatan, dan Subsidi Jumlah biaya operasional angkutan mempengaruhi tingkat penentuan tarif optimum yang dibebankan. Perhitungan tarif optimum dilakukan berdasarkan SK Dirjen Perhubungan Darat No. 687 tahun 2002 dimana tarif dihitung berdasarkan $70 \%$ dari total kapasitas muat penumpang. Tarif yang ditetapkan saat ini yakni Rp. 5.000 untuk trayek PS - KE dan Rp. 10,000 pada trayek PS - KB, telah sesuai dengan standar diatas dan sesuai dengan kemauan dan kemampuan membayar masyarakat (willingness to pay dan ability to pay).

Namun kondisi penggunaan layanan yang rendah menyebabkan pemerintah harus memberikan subsidi yang sangat besar terhadap tarif tersebut. Pada trayek PS - KE pemerintah harus mensubsidi sebesar Rp. 17.339,23 per Pnp-Trip dan pada trayek PS - KB sebesar Rp. 11.739,82 per Pnp-Trip.
Tabel 4.3 Tingkat Tarif Trayek AMB

\begin{tabular}{|c|c|c|c|}
\hline No. & Komponen & $\begin{array}{l}\text { Trayek } \\
\text { PS - KE } \\
\end{array}$ & $\begin{array}{l}\text { Trayek } \\
\text { PS - KB } \\
\end{array}$ \\
\hline 1 & $\begin{array}{l}\text { Biaya Operasional } \\
\text { per Trip Kendaraan } \\
\text { (Rp/Kend-Trip) }\end{array}$ & $\begin{array}{r}95.902,3 \\
1\end{array}$ & $\begin{array}{r}189.829,5 \\
1\end{array}$ \\
\hline 2 & $\begin{array}{l}\text { Passenger Load } \\
\text { Factor (\%) }\end{array}$ & $15,90 \%$ & $42,00 \%$ \\
\hline 3 & $\begin{array}{l}\text { Kapasitas } \\
\text { Kendaraan (Seat) }\end{array}$ & 27 & 27 \\
\hline 4 & $\begin{array}{l}\text { Jumlah Penumpang } \\
\text { / Trip Kendaraan } \\
\text { (Pnp/Kend-Trip) }\end{array}$ & 4,293 & 11,34 \\
\hline 5 & Tarif Dasar (1/4) & $\begin{array}{r}22.339,2 \\
3 \\
\end{array}$ & $16.739,82$ \\
\hline 6 & $\begin{array}{l}\text { Tarif } \quad \text { Berlaku } \\
\text { (Rp/Trip-Pnp) }\end{array}$ & 5.000 & 10.000 \\
\hline
\end{tabular}

Sumber: Analisis, 2017

Tingkat pendapatan kedua trayek AMB masih sangat rendah. Hal ini dipengaruhi oleh tarif yang sangat murah dibandingkan tarif berdasarkan biaya operasional dan juga tingkat penggunaan layanan yang jauh di bawah standar. Dengan passenger load factor hanya sebesar 15,90\% pada trayek PS - KE dan $42,00 \%$ pada $P S-K B$, pendapatan dari tarif tidak mampu menutupi biaya operasional. Rasio cost recovery untuk kedua trayek AMB masih sangat rendah yaitu trayek PS - KE sebesar 22,61\%, dan trayek PS KB sebesar $56,18 \%$. Perbandingan antara biaya operasional, pendapatan operasional, dan subsidi operasional ditampilkan pada Tabel 5-36 berikut.

Tabel 4.4 Perbandingan Tingkat Biaya

Operasional, Pendapatan Operasional, dan Subsidi Operasional

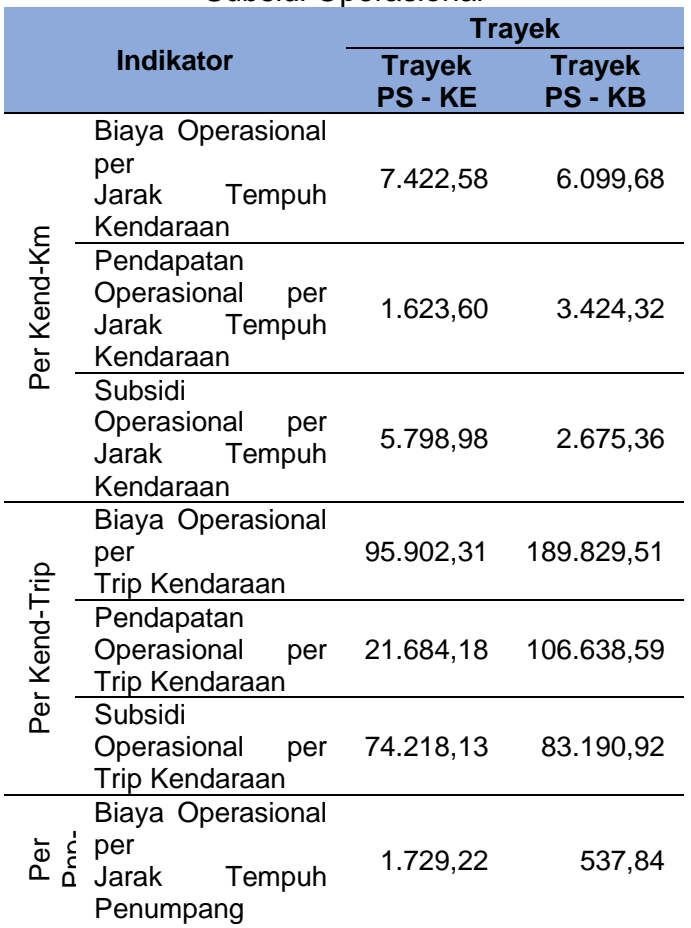




\begin{tabular}{lcr} 
& \multicolumn{2}{c}{ Trayek } \\
\cline { 2 - 3 } Indikator & $\begin{array}{c}\text { Trayek } \\
\text { PS - KE }\end{array}$ & $\begin{array}{c}\text { Trayek } \\
\text { PS - KB }\end{array}$ \\
\hline $\begin{array}{l}\text { Pendapatan } \\
\text { Operasional per } \\
\text { Jarak Tempuh }\end{array}$ & 390,99 & 302,14 \\
$\begin{array}{l}\text { Penumpang } \\
\text { Subsidi }\end{array}$ & & \\
$\begin{array}{l}\text { Operasional per } \\
\text { Jarak Tempuh } \\
\text { Penumpang }\end{array}$ & $1.338,23$ & 235,70 \\
& & \\
Pumber: & &
\end{tabular}

Sumber: Analisis, 2017

\section{c. Kondisi Kemampuan Finansial Pemerintah}

Kelangsungan pelayanan AMB secara finansial akan sangat bergantung pada kemampuan pemerintah daerah mendanai seluruh kegiatan pengoperasian AMB. Pada Tabel 9 dilakukan perbandingan antara total pengeluaran pemerintah dan ketersediaan pendanaan pengoperasian $\mathrm{AMB}$.

Tabel 4.5 Kondisi Finansial Pemerintah Daerah Untuk Pembiayaan AMB

\begin{tabular}{|c|c|c|}
\hline & Tahun 2015 & Tahun 2016 \\
\hline $\begin{array}{l}\text { Biaya } \\
\text { Operasiona } \\
\text { I }\end{array}$ & $\begin{array}{l}2.545 .063 .941,0 \\
5\end{array}$ & $\begin{array}{l}2.408 .824 .554,2 \\
2\end{array}$ \\
\hline $\begin{array}{l}\text { Subsidi } \\
\text { Operasiona } \\
\text { I }\end{array}$ & $\begin{array}{l}1.281 .964 .941,0 \\
5\end{array}$ & $\begin{array}{l}1.731 .535 .636,7 \\
6\end{array}$ \\
\hline $\begin{array}{l}\text { Total } \\
\text { Pendanaan } \\
\text { AMB }\end{array}$ & $\begin{array}{l}3.827 .028 .882,1 \\
0\end{array}$ & $\begin{array}{l}4.140 .360 .190,9 \\
8\end{array}$ \\
\hline $\begin{array}{l}\text { Alokasi } \\
\text { Anggaran } \\
\text { APBD }\end{array}$ & $\begin{array}{l}7.545 .475 .000,0 \\
0\end{array}$ & $\begin{array}{l}7.625 .400 .000,0 \\
0\end{array}$ \\
\hline
\end{tabular}

Sumber: Analisis, 2017

Dari perbandingan diatas, pada dasarnya pemerintah Kabupaten Teluk Bintuni memiliki kemampuan finanasial yang besar untuk mendanai pengoperasian AMB.

\section{Kesimpulan}

Transportasi umum di kawasan perkotaan Bintuni di Provinsi Papua Barat cenderung terabaikan karena tidak memberikan kelayakan finansial bagi pelaksana angkutan. Namun dengan semakin meningkatnya keuangan daerah dan bantuan dana CSR dari British Petroleum (BP) Berau Ltd., Pemda Kabupaten Teluk Bintuni menerapkan konsep angkutan umum massal berbasis bis di kawasan perkotaan Bintuni yakni Angkutan Masyarakat Bintuni (AMB).

AMB beroperasi dengan dua trayek utama yaitu Trayek Pasar Sental - Kompi E (trayek PS - KE) dengan wilayah pelayanan di internal Distrik Bintuni dan Trayek Pasar Sentral - Kantor Bupati (Trayek PS - KB). Tantangan yang dihadapi oleh pemerintah setelah AMB beroperasi adalah memastikan kelangsungan layanan. Sehingga pengukuran efisiensi dan efektivitas menjadi hal yang penting untuk dilakukan dalam rangka memastikan kelangsungan dan meningkatkan tingkat pelayanan AMB.

Trayek PS - KE memiliki tingkat kinerja efisiensi biaya yang lebih baik karena biaya operasional dan subsidi operasional yang lebih kecil untuk setiap trip kendaraan yang diproduksi. Namun kinerja efisiensi biaya yang lebih baik ini tidak diikuti dengan tingkat penggunaan layanan yang tinggi sehingga untuk kinerja efektivitas pelayanan dan efektivitas biaya pada trayek ini masih rendah.

Trayek PS - KB memiliki tingkat kinerja efektivitas pelayanan dan efektivitas biaya yang lebih baik karena jumlah pengguna trayek yang lebih banyak dan tarif angkutan yang lebih tinggi. Walaupun efisiensi biaya untuk memproduksi layanan tergolong rendah namun konsumsi layanan oleh pengguna dan pendapatan dari tarif yang dibayarkan dapat mengimbangi biaya tersebut.

Masih rendahnya kinerja AMB dari sisi finansial disebabkan oleh tingkat efisiensi dan efektivitas biaya dan pelayanan yang rendah dimana tingginya biaya produksi layanan angkutan yang tidak dapat diimbangi dengan pendapatan dari konsumsi layanan oleh pengguna dan tarif yang dibebankan. Dengan intensitas penggunaan layanan yang kecil, tingkat tarif yang sangat jauh dari standar ideal dan disesuaikan dengan kemampuan dan kemauan membayar masyarakat, maka cost recovery layanan ini masih rendah dan sangat bertumpu pada subsidi pemerintah. masyarakat.

Strategi yang dapat dilakukan untuk meningkatkan efisiensi dan efektivitas pelayanan AMB adalah mengurangai biaya operasional angkutan dengan pengurangan proporsi biaya BBM dengan menstabilkan pasokan dan harga di Bintuni. Pemerintah Bintuni harus dapat meningkatkan jumlah pengguna layanan angkutan AMB dengan memperluas jaringan pelayanan ke seluruh wilayah perkotaan sehingga setiap kawasan terbangun memiliki kemudahan dalam mengakses layanan angkutan AMB. Restrukturisasi tarif perlu dilakukan untuk menjangkau seluruh lapisan ekonomi masyarakat dan meningkatkan kompetisi dengan angkutan ojek.

Dengan kapasitas keuangan untuk pengoperasian layanan AMB yang besar, dan terdapat ruang untuk perbaikan kualitas layanan angkutan, Pemerintah Daerah bertanggung jawab untuk terus menyediakan layanan dasar transportasi demi memberikan pelayanan dasar hidup masyarakat. Pemerintah harus dapat mengoperasikan layanan AMB dengan tingkat efisiensi dan efektivitas pelayanan yang lebih baik tanpa mengurangi tingkat pelayanan terhadap penduduk. 


\section{Daftar Pustaka}

Diana, M., \& Daraio, C. (2010). Performance indicators for urban public transport systems with a focus on transport policy effectiveness issues. In Lisbon: Paper in World Conference on Transport Research,(WCTR, 2010).

Direktorat Jenderal Perhubungan Darat. (2003).

Surat Keputusan Direktor Jenderal Perhubungan Darat nomor SK.687/AJ.206/DRJD/2002 tentang Pedoman Teknis Penyelenggaraan Angkutan Penumpang Umum di Wilayah Perkotaan dalam Trayek Tetap dan Teratur. Jakarta.

Eboli, L., \& Mazzulla, G. (2011). A methodology for evaluating transit service quality based on subjective and objective measures from the passenger's point of view. Transport Policy, 18(1), 172-181.

Fielding, G.J., Glauthier, C., Lave, C.A., 1978. Performance indicators for transit management. Transportation 7, 365-379.

Fielding, G. J., Babitsky, T. T., \& Brenner, M. E. (1985). Performance evaluation for bus transit. Transportation Research Part A: General, 19(1), 73-82.

Florida Department of Transportation. (2014). Best Practices In Evaluating Transit Performance (Final Report). State of Florida. Freight Logistics and Passenger Operations, Transit Office.

Giannopoulos, G.A. (1989). Bus planning and operation in urban areas: A practical guide. Avebury, Aldershot, UK, 370pp

Hensher, D. A., \& Gabriel, Wong. (2011). Different Approaches to Public Transport Provision. Editorial Team, 31-41.

Karlaftis. M.G. \& Tsamboulas, D. (2012) Efficiency measurement in public transport: Are findings specification sensitive? Transportation Research Part A, 46, 392402.

Kerstens, K., 1996. Technical efficiency measurement and explanation of French urban transit companies. Transportation Research Part A 30 (6), 431-452.

Kusbiantoro. (1985). A Study Of Urban Mass Transit Performance: Concept, Measurement, And Explanation. University of Pennsylvania.

Purba, A. (2015). A Study On Evaluating Urban Bus Service Performance In Developing Countries: Case Studies Of Medium-Sized Cities In Indonesia. (Doctoral dissertation, Yokohama National University).

Sianturi, R,D. (2017). Studi Kinerja Keberlanjutan Pelayanan Operasional Angkutan Bis Perkotaan di Kawasan Perkotaan Bintuni. Program Studi Magister Transportasi Institut Teknologi Bandung.

Sheth, C. H. (2003). The Measurement and Evaluation of Urban Transit Systems: The
Case of Bus Routes (Doctoral dissertation, Virginia Tech).

Velaga, N. R., Nelson, J. D., Wright, S. D., \& Farrington, J. H. (2012). The potential role of flexible transport services in enhancing rural public transport provision. Journal of Public Transportation, 15(1), 7.

Yayasan Pengembangan Teluk Bintuni. (2012). Penyusunan Rencana Strategis Pengembangan Sistem Transportasi Kabupaten Teluk Bintuni. Bintuni.

Yayasan Pengembangan Teluk Bintuni. (2014). Penyusunan Rencana Persiapan Pelaksanaan Pengembangan Sistem Transportasi Bis Kota Bintuni. Bintuni.

Zuriyati, Rahmah. (2015). Evaluasi Efektivitas dan Efisiensi Pelayanan Operasional Angkutan Bus Damri di Kawasan Perkotaan Bandung. Program Studi Magister Transportasi Institut Teknologi Bandung. 